\title{
THE PROTECTION OF FAMILIES \\ IN THE SLOVAK LEGAL SYSTEM
}

\section{LILLA GARAYOVÁ}

\section{Introduction}

The union of a man and a woman, recognized by authority or rite, is as old as civilization itself, and marriage in some form is found in virtually every society. Throughout the centuries, marriage has taken many forms, and, in some ways, it barely resembles the meaning it once held. The primary purpose of marriage thousands of years ago was to bind a woman to a man, thereby guaranteeing that their common children were indeed their biological heirs. Through marriage, a woman became the man's property. Early marriage in ancient societies was accompanied by the need to ensure a safe environment for the preservation of the tribe. In these early times, marriage was often without love and desire, because the main motivation to enter into a marital bond was social and economic stability. The foundations of marriage remained unchanged for thousands of years, and the first major transformation of this institute started with universal suffrage in the twentieth century. The idea that marriage is a private relationship for the fulfillment of two individuals is very new, and due to the rapidly changing society in the twentieth century, the institute of marriage has changed more in the past 50 years than in the 5000 years before. If the evolution of marriage and family is virtually the same across the globe, why are the guiding principles of family law so different, even for countries within the same region? Should family law reflect the values of each country? Is there a way to

Lilla Garayová (2021) The Protection of Families in the Slovak Legal System. In: Tímea Barzó, Barnabás Lenkovics (eds.) Family Protection From a Legal Perspective, pp. 221-254. Budapest-Miskolc, Ferenc Mádl Institute of Comparative Law-Central European Academic Publishing. 
create a unified family law that is palatable to all European (EU) countries? Will the Visegrád Four (V4) countries, with a more traditional interpretation of family law, keep their values, or will they step onto the path of Europeanization?

Family law is a set of legal norms governing personal relationships and related property relationships between spouses and between parents and children, as well as relationships imitating or replacing them. The subject of Slovak family law consists of three basic types of family law relationships:

- relationships between spouses - these arise from the free and voluntary declaration of a man and a woman that they are getting married,

- relationships between parents and children (and through them, also among other relatives),

- relationships of surrogate family care - these are relationships that replace the relationship between parents and children (foster care, guardianship) and relationships that mimic the relationship between parents and children (adoption).

The primary source of our national family law is the Constitution of the Slovak Republic $^{1}$ as the basic law of the state, which, in Art. 41, enshrines the principles of family law, from which the legal provisions contained in the Family Act are derived. Since January 19, 2005, the legal norms governing family law relations are contained in Act No. 36/2005 Coll. on the family (hereinafter referred to as the Family Act) ${ }^{2}$. The Family Act is a separate act, which is the primary source of family law, among many others. It can be said that the Family Act has become well established in society and has been generally accepted relatively quickly. It was not significantly amended until 2015; prior changes were minor and only affected the institute of pre-adoption care, the institute of substitute alimony, and the institute of alternating care. The biggest change came in 2015, whereby the principles contained in the Family Act were amended, placing a greater emphasis on the best interests of the child, with the intention of creating a modern family law more in line with European standards. As a result, the basic principles concerning the criteria of the best interests of the child were expanded, the conditions for placing a child in institutional care were tightened, and the priority position of substitute personal care was emphasized. These changes occurred with the adoption of Act No. 175/2015 $\mathrm{Coll.}^{3}$ In response to current societal trends, namely the decline of the traditional family where the child's mother and father live in marriage, higher divorce rates, the growing number of children born out of wedlock, international child abductions and the related improvements in child protection, and, last, the importance of a stable family environment that includes the father and the mother.

The Ministry of Justice of the Slovak Republic and the Ministry of Labor, Social Affairs and Family of the Slovak Republic cooperated in the preparation of the bill,

1 Constitution of the Slovak Republic of 1992 (460/1992 Coll.).

2 Act No. 36/2005 on Family and on Amendment of Other Acts.

3 Act No. 175/2015 Coll. 
with the aim of strengthening the protection of children's interests. The joint proposal of the two ministries received great support in the legislature, with 98 members of parliament (larger than the constitutional majority) voting for it.

Most importantly, the amendment to the Family Act established the environment of the family formed by the father and the mother of the child as the most suitable environment for the all-round and harmonic development of children. Another change was on the issue of the best interests of the child. We consider this step by the legislator to be positive and desirable, as before the adoption of Act No. 175/2015 Coll. This term was not defined, although the Family Act refers to it in many places (but it is a term used and referenced in many other laws that had not been defined previously) and highlights it as a basic criterion, for example, in the decision-making activity of the courts and of all the authorities in general, in the absence of its definition, its determining criteria were left to the discretion of the courts.

The current family law in Slovakia is at a crossroads. The basic principles of family law enshrined in the Constitution and the Family Act are based on inherently traditional values, whose aim is to protect the traditional family. In recent years, however, there has been increasing pressure from the EU to reform Slovak family law, move towards Europeanization, and adopt modern trends in family law. While society is undeniably changing, and the current legal framework does not fully reflect that (there are no provisions on cohabitation or civil partnership; there are no alternatives to traditional marriage). Slovak society at its core remains mostly conservative; therefore, the values that provide the foundation of family law principles reflect this disposition. The following chapter looks at the evolution of family law, the core principles of family law, and the protection of matrimony and families in family law in an attempt to identify the reason behind the conservative nature of Slovak family law, its future, and the resilience of its traditional values against modern trends.

\section{The evolution of family law and the creation of its basic principles in the Slovak Republic}

Family law is one of the oldest legal disciplines in private law. This is because, since time immemorial, it has applied to the interests of the most private nature of an individual -spouses, parents, children, or other persons holding family rights and responsibilities.

Family law relations in the Slovak legal system are regulated by the Family Act. Since 1950, family law relations have been set outside the scope of the Civil Code and are still regulated by a separate law. In the future, however, the regulation of family relations will be returned to the Civil Code as a separate part of it in the framework of the forthcoming codification of general private law in Slovakia. 
In terms of the current relationship between family and civil law, the return to the dual structure of private and public law after 1989 means that the regulation of personal and property conditions in the family and marriage is closely linked to general civil law. The integration of both subsystems of private law is evident even now, especially in $\S 111$ of the Family Act, which provides for the general subsidiarity of the Civil Code for legal relations regulated by the Family Act. Thus, unless the Family Act provides otherwise, the provisions of the Civil Code shall apply to family relationships.

Until 1949, family law was not uniformly regulated and codified in the territory of the Slovak Republic. Legal relations in the family were regulated by their nature through several civil law regulations. After the First World War, after the Czechoslovak Republic was established, Act No. 11/1918 ${ }^{4}$ reciprocated the then AustroHungarian law, with some exceptions. In Slovakia, the reception standard took over Hungarian civil law, which was mostly an unwritten customary law. Of the written regulations concerning family law relations, the most important was the Marriage Act (Act No. XXXI/1894) ${ }^{5}$, which regulated in detail the conditions for the formation and dissolution of marriage. The law was based on the contractual nature of marriage, introduced obligatory civil marriage, and allowed separation, regardless of the confessional affiliation of the spouses. The content of the marital relationship and the rights and obligations of the spouses were, however, not regulated by the Marriage Act and were therefore governed by customary law. Another important legal act that was reciprocated was Act No. XX/1877 on guardianship and custody. Many questions on family law, however, remained a murky gray area; because of this legal dualism (sometimes even trialism of Austrian, Hungarian, and customary law, with further differences between customary laws of different regions of the newly formed state), the newly established state prioritized the unification of laws.

Shortly after the reception of the Austro-Hungarian regulations, some questions on matrimonial law were unified in 1919. The Amending Act on Marriage (Act No. $320 / 1919$ Coll. $)^{6}$ was undoubtedly the most important step in the path of an independent Czechoslovak legislation during the first republic. The Act uniformly regulated the formation of marriage, marital obstacles, and the dissolution of marriage. The Amending Act on Marriage introduced an optional civil marriage in addition to a valid church marriage. It exhaustively adjusted the reasons for separation after marriage. This Act was revolutionary in a sense, since it unified matrimonial law in that it applied to all citizens of the Republic, regardless of religion. The Act broke the principle of the inseparability of Catholic marriage during the lifetime of the spouses. The previous Austro-Hungarian marriage law granted the possibility of separation

\footnotetext{
4 Act No. 11/1918 Reception Act, Section 2 stipulated that 'all existing regional and imperial laws and regulations shall continue to be in force temporarily' in order 'to avoid any confusion and to regulate an unobstructed transition to a new life of the State'.

5 Marriage Act (Act XXXI/1894).

6 Act No. 320/1919 Coll.
} 
only to non-Catholics, and Catholic marriage was separable only by death. For the Czechoslovak population, the marital amendment represented a transition from the irrevocability of marriage to the possibility of its annulment by separation in a new, yet desirable, way and corresponding to the needs of the people. It exhaustively regulated the methods of marriage separation and kept in force the institute of separation 'from bed and board', which, although it did not mean the dissolution of the marriage, relieved the spouses of the obligation to live together.

Regarding the analysis of Act No. 320/1919 Coll., it is also necessary to consider that the territory of the then Czechoslovak Republic was newly created. In addition to the so-called historical countries, it also includes Slovakia and Subcarpathian Ruthenia. These huge territorial changes after the World War were much more than merely new borders; they also meant legal transformation and connection of the various territorial units of the newly formed country via law. The social, religious, and other differences affecting family life were also palpable between these territorial units; therefore, these differences had to be considered in the new legislation as well. While the act tried to incorporate all these challenging areas and brought a new perspective on family law, much less affected by religious affiliation than ever before, it also involved a range of future problems that legislators never managed to overcome during the first Czechoslovak Republic.

Despite the unification tendencies discussed above, several issues remained fractured in the new legislation. For example, the issue of adjusting the joint property of spouses remained different in Slovakia from that of the other territories of the country. In Czechia, Moravia, and Silesia, the system of separate property of spouses was applied with a wide range of contractual modifications through so-called marriage contracts. In Slovakia, the institute of co-acquisition was applied, which represented a system of property community in case of marriage dissolution.

The fundamental political changes in Czechoslovakia after February 1948 were reflected in the entire legal order. The new communist government within the socalled biennial of legal proceedings launched a revision of legal regulations, which also affected the area of family law. The first Act on Family Law No. 265/1949 Sb. ${ }^{7}$, which entered into force on January 1, 1950, became, among other things, a legislative expression of the ideological principles of the new socialist law, which abandoned the classification of public and private law. The Act on Family Law brought many important changes to legal provisions on family relationships. It elaborated on the family law regarding the basic principles expressed in the May 1948 Constitution. Legal provisions on family were separated from general civil law, and family law provisions were unified for the entire territory of the country. This Act featured an obligatory civil wedding, full equality of the husband and the wife in their rights and obligations, the removal of discrimination of children whose parents did not enter marriage, and the reduction of impediments of marriage. The Act on Family Law undoubtedly represented the legislator's undertaking to get marriage and family

7 Act on Family Law No. 265/1949 Sb. 
life under the control of the state. The Act itself had the status of a separate legal regulation; therefore, it did not contain any provision that would create its specialty in relation to the Civil Code as a general, applicable regulation; therefore, the act meant the complete separation of family law and civil law.

The 1949 Act was based on the principle of equal status for men and women and the equal legal status of children born in and out of wedlock. A complete secularization of the marriage was carried out, and the formation of the marriage was obligatorily linked to civil marriage. The law abandoned the concept of marriage as a contractual relationship and replaced it with the consent of the spouses to voluntarily enter marriage before the relevant national committee in the presence of two witnesses. When it comes to the dissolution of a marriage, the distinction between divorce and separation 'from bed and board' was removed. The only way to dissolve a marriage became a decision of the court.

The Act on Family Law from 1949 was amended twice during its short period of validity. The first amendment was made by Act 61/1955 Coll. on the amendment to divorce regulations. This amendment alleviated the impossibility of dissolving a marriage without the consent of the spouse, by a court decision, which, in exceptional cases, allowed the court to declare a divorce in its decision if the marriage had been permanently and deeply dysfunctional for a long time. The second amendment was made by Act No. 15/1958 on the amendment of the regulations on adoption, in which the adoptive parents were entered in the register, instead of the biological parents.

The Act on Family Law did not survive for a long time. In 1960, Czechoslovakia adopted a new socialist constitution. Under ideological influence, they mistakenly anticipated the victory of socialism and subsequent social development. These misconceptions were legally expressed in the new constitution, and shortly thereafter, the basic branches of law were recodified. Important changes in the legal order ensued, affecting all areas of law, including family law and matrimonial law. The result of the second wave of socialist codification of law was the new Family Act No. 94/1963 Coll. ${ }^{8}$ The new law entered into force on April 1, 1964, and was in force until April 1, 2005. The new Family Act followed the main principles of the regulation of individual institutes in the Family Law Act of 1949, with much greater emphasis on the paternalistic understanding of the relationship between the state and the family. The biggest changes affected the regulation of divorce and some basic principles of marriage. The opening provision of the Act stated that 'the morality of socialist society should become the basis for all relationships in family, for the marriage itself, and for raising children. ${ }^{9}$ Therefore, the previously separate provisions on the legal protection of children and youth were incorporated into this Act, and the powers of National Committees in terms of social control of raising children were substantially enlarged. Based on the Family Act, the family became the basic building block of society, where parents were responsible for the mental and physical development of 
their children, with the state and other social organizations being also ascribed some responsibilities in terms of raising children and fulfilling their material needs.

The Act maintained the obligatory civil wedding: the wedding had to be performed in front of a state authority, with limited exceptions from this provision. The dissolution of the marriage was largely impacted by this act as well, and the courts were supposed to investigate the causes of the breakdown of the marriage, but they were to abstain from providing a formal verdict on the guilt in divorce proceedings. The courts were also supposed to include a decision concerning the parents' rights and duties after the divorce with respect to their minor children. The concepts of wardship and guardianship were replaced by a single concept of guardianship, and wardship was assigned to state authorities, further emphasizing the growing state control.

The dissolution of the Czechoslovak federation simultaneously meant the birth of new successor states - Slovakia and the Czech Republic - on January 1, 1993. After the establishment of the Slovak Republic, the Family Act of 1963, as amended, became the basis for the regulation of family law in Slovakia as stated in the reception norm contained in Art. 152 of the Constitution of the Slovak Republic. In the mid-1990s, in discussions on the new concept of legal regulation of relations under private law, expert opinions prevailed that understood the normative regulation of family law as an integral and natural part of the forthcoming recodification of the Civil Code. In other words, family law, together with other branches of private law, should be concentrated in the new Civil Code. Currently, this is still in the realm of the future evolution of family law.

The new Family Act No. 36/2005 Coll. was not originally included in the Plan of Legislative Tasks of the Slovak Republic. The plan required the Ministry of Justice of the Slovak Republic to prepare only an amendment to the Family Act No. 94/1963 Coll. as amended. However, the scope of the proposed changes exceeded the possibilities of direct amendment of the law and required not only a change in the system of the law but also the adoption of a completely new legislation. The previous legislation was modern at the time and was in force for over 40 years. In the twenty-first century, however, it has not been able to respond sufficiently to the dynamic development and fundamental changes that have taken place in society.

The new legislation from 2005 already reacts to the Convention on the Rights of the Child as well as to the legislative intention to recodify the Civil Code, which will also include the integration of family law into the Civil Code. In the preparation of the new Family Act, a comparison with foreign legal systems (Hungary, Germany, the Czech Republic, etc.) was also partially used.

According to the explanatory report of the new Family Act in 2005, the changes introduced by the new legislation effective from April 1, 2005 concern the grounds for invalidity and non-existence of marriage in circumstances excluding marriage, the possibility of regulating the child's contact with close persons, distinguishing between guardianship and wardship institutes. Compared to the previous regulation, the rules for monitoring and evaluating the performance and effectiveness of 
institutional education, educational measures, the performance of the guardian, and the guardian's administration of the child's property have been tightened. The issue of foster care regulation was also included in the new law. Although it has public law elements, by its nature, it is mainly a private law institution of substitute family foster care.

In view of the current developments in medical science, as well as in foreign practice, the increasingly frequent disputes over the determination of maternity law express the principle that the mother of a child is the woman who gave birth to the child. In this context, it was necessary to clearly enshrine the invalidity of any contracts and agreements that run counter to the irrebuttable presumption of maternity.

\section{The basic principles of Slovak family law}

The core sources of Slovak family law are the Constitution of the Slovak Republic and the Family Act of 2005. While a closer look at all the provisions of these Acts would be impossible due to the limitations of this publication, I believe a look at the basic principles of Slovak family law is essential in understanding the state of family law in Slovakia in comparison with other EU countries. The Family Act of 2005 contains a list of basic principles in its first provision. In essence, these basic principles represent the pillars on which the Slovak family law was built. These are the most important provisions of national family law, with the possible exception of Art. 41 of the Constitution of the Slovak Republic, which represents the framework of the entire family law regulation. The purpose of the basic principles lies mainly in that they serve as common rules for the interpretation of family law. It is necessary to look at every family law relationship through the lens of these principles, and the rights and responsibilities of each subject involved must be assessed based on these principles. An interesting common feature of these principles is that while family law is inherently private, unlike most private law principles, these principles are not only aimed at determining the relationship between two private entities, but also outline the responsibilities of the state and society in relation to the family and its protection. They provide answers to questions about which types of family relationships are preferred or prioritized by the state and what they should entail. For this reason, no public authority may use discretion in interpreting family law relationships that would run contrary to the pillars of family law. These basic principles are enshrined in Arts. 1-5 and represent the values and principles of family law in Slovakia.

Art. 1: Marriage is a union of a man and a woman. The society comprehensively protects this unique union and helps its welfare. Husband and wife are equal in their rights and 
responsibilities. The main purpose of marriage is the establishment of a family and the proper upbringing of children.

Marriage, understood as a union of two people who are close and irreplaceable to each other, is still the most desirable form of human coexistence. According to research by psychologists, marriage is extremely important for a person's physical and mental health. ${ }^{10}$ These studies have shown that married people live longer and have happier lives. ${ }^{11}$ There is less violence in it than in unmarried cohabitation or between singles. ${ }^{12}$ Marriage requires a person to emotionally invest in a relationship, which has a positive effect on his or her personal well-being. It creates new social ties, integrates a person into social groups, and strengthens their position in society. It not only plays a key role in one's family life but also directly affects society. Naturally, all these positive tasks are only performed in a marriage that is functional and working. The Family Act interprets its function through the principle of equality of spouses. This equality must be understood not only as equality in rights between spouses but also as equality in responsibilities. Each spouse contributes to the well-being of the family according to their possibilities, abilities, and material conditions. The equality of spouses is reflected in the position of each of them as a partner and as a parent. Neither sex should be discriminated against when assessing the legal status of a marriage. When evaluating a dispute, in each individual case, it is necessary to assess separately how the spouses enjoy the rights derived from their marriage and how they fulfill their obligations.

Marriage under Slovak law is still a union between a man and woman. This provision has even been incorporated into Art. 41 of the Constitution of the Slovak Republic, being the only legislative change that this article has gone through since the Constitution came into effect. To date, no legal alternative to marriage exists in the Slovak legal order (more details on this are given in the following chapters). This is rooted in the traditional view of family law in the Slovak legal order and emphasizes the biological-reproductive function of the family.

\section{Art. 2: 'Family founded by marriage is the basic cell of society. Society comprehensively} protects all forms of the family.'

The term 'family' is understood more broadly than just a 'family established by marriage.' Every form of family is protected and supported by the state, regardless of how it was formed, if it gives its members a sense of security and solidarity. Even under the International Covenant on Civil and Political Rights, ${ }^{13}$ the 'family is the

10 Uecker, 2012, pp. 67-83.

11 Stavrova, 2019.

12 Kenney and McLanahan, 2006.

13 Art. 23 of the International Covenant on Civil and Political Rights, Adopted and opened for signature, ratification, and accession by General Assembly resolution 2200A (XXI) of 16 December 1966, entry into force 23 March 1976, in accordance with art. 49. 
natural and fundamental group unit of society and is entitled to protection by society and the State.' The Covenant further declares the right of every man and woman of marriageable age to marry and to found a family. This right is closely linked to the right to respect for private and family life as outlined in the European Convention on Human Rights. ${ }^{14}$ The Family Act highlights marriages that have fulfilled their main purpose within the meaning of Art. 1 of the Basic Principles and have created a family, which forms the basis of society and which society is committed to protecting comprehensively. Based on this principle, a family is a group of at least one parent and at least one child. In principle, it is not possible to participate in any discrimination of other marriages (i.e. marriages that have remained childless) because these unions are also protected by Art. 1, Basic principles. It can therefore be assumed that the protection provided in this article is a special type of protection that goes beyond the general principle of Art. 1.

Art. 3: Parenting is a mission of men and women recognized by society. The society recognizes that a stable family environment formed by the child's father and mother is the most suitable for the all-round and harmonious development of the child. Therefore, the society provides parents not only with its protection, but also with necessary care, especially with material support for parents and assistance in the exercise of parental rights and responsibilities.

One of the most important functions of a family is its educational function. Being a parent means taking responsibility for the proper upbringing of a child. When analyzing Art. 3 of the Family Act, a comparison with its predecessor from 1963 shows significant differences. The 1963 Family Act stated that 'Motherhood is a woman's honest mission. Society provides motherhood not only with its own protection, but also with all its care, especially with material support for mothers and children and assistance in their upbringing'. ${ }^{15}$ As opposed to the 1963 wording, the 2005 legislation no longer refers to motherhood as the woman's mission; it clearly reflects a shift in societal values by using terms such as 'parenthood' and 'parenting'. This further supports the principle of equality of spouses in marriage, both in their rights and their responsibilities. Trends regulating the boundaries between family privacy and state interest are currently leaning toward the theory of responsibility for the exercise of parental rights and obligations. As stated by the Constitutional Court of the Czech Republic, conceiving a child is not a sport or a pastime, although it may seem that way to some individuals at the beginning. In reality, however, future parents assume duties and responsibilities that accompany them throughout their lives, often until their own death. Therefore, it is essential that they behave in such a way that they can always and in all circumstances meet their obligations and

14 Convention for the Protection of Human Rights and Fundamental Freedoms, 1950, art. 8.

15 Family Act No. 94/1963 Coll. 
responsibilities. ${ }^{16}$ If the parent naturally performs this function properly, the state provides help and support with respect to both privacy and social care. However, if the proper upbringing of a child is endangered or disrupted, the Family Act gives the court the right to take measures to remedy this situation without a proposal. For this reason, Art. 3 of the Basic Principles was supplemented in 2016 by a second sentence stating that society recognizes that a stable family environment formed by the child's father and mother is the most suitable for the all-round and harmonious development of the child. This formulation clearly favors the traditional family union of a man and a woman and their children over other forms of cohabitation. This amendment established the family environment formed by the child's father and mother as the most suitable environment for the all-round and harmonious development of the child. This is primarily to express society's belief that the competent authorities and institutions, which may affect the child and their rights, are obliged to respect the fundamental rights of the child ( while considering the circumstances), growing up from birth in a natural family environment. This emphasizes the importance of parents for the child's healthy, versatile, and harmonious development. On the other hand, the definition in question resulted in many debates before the amendment, because according to some experts, the wording of this sentence in its current form may be discriminatory. It could, in a sense, indicate that a family in which one of the parents is absent is incomplete and unable to fulfill its potential completely, not considering the multitude of reasons such an absence may occur, such as the death of one of the parents. There were concerns that while the intention behind this principle is clearly a positive one (to protect the rights of the child), when it comes to the application, this provision might result in discrimination or, in certain divorce cases, the judge's efforts to preserve a broken marriage for the sake of the minor.

The change in the wording of this principle is a very positive one, declaring that parental rights and responsibilities belong to both parents and that both holders of parental rights and responsibilities, namely mother and father, are equal in their parental rights and responsibilities; therefore, no discrimination is acceptable in this area.

Art. 4: All family members have a duty to help each other and, according to their abilities and possibilities, to ensure the increase of the material and cultural level of the family. Parents have the right to raise their children in accordance with their own religious and philosophical beliefs and the obligation to provide the family with a peaceful and safe environment. Parental rights and responsibilities belong to both parents.

16 From the ruling of the Supreme Court of the Czech Republic 4 Tdo 250/2012-24. The Supreme Court of the Czech Republic ruled in a closed session held on April 18, 2012 on an appeal filed by the accused V. J. Against the resolution of the Regional Court in Hradec Králové of November 24, 2011, file no. 10 To 368/2011, in a criminal case conducted at the District Court in Jičín under file no. 8 T $57 / 2011$. 
Family solidarity is the basis for fulfilling the family's socio-economic functions. It concerns all members of the family without distinction, and its understanding reflects the morals of society. Contributing to the prosperity of the group should naturally be inherent in everyone, more so in the case of a family, since it is the primary social unit to which an individual belongs.

This solidarity means more than just finances. The law also understands it as the basis of mutual assistance and support. The obligation to participate in meeting the needs of the household is expressly imposed by law. All rights and obligations of family members must be comprehensively understood and assessed comprehensively. None of its members can only have obligations or only enjoy rights.

The moral and ethical principles of this provision are further detailed in the provisions of $\S 18$ and $\S 19$ of the Family Act, according to which all family members (children included) are obliged to help each other and according to their abilities and possibilities. Parents are further granted the right to raise their children according to their own religious, philosophical, or ideological beliefs, but this right of parents should directly respect the rights of the child guaranteed by Art. 14 of the Convention on the Rights of the Child - the right to freedom of thought, conscience, and religion. It is the duty of parents to ensure a harmonious environment in which all family members feel safe. This principle is further extended by the amendment expressed in several provisions of the normative part of the Family Act (§28, §35, etc.), namely that both holders of parental rights and obligations - that is, mother and father - are equal in their parental rights and obligations; therefore, no form of discrimination in this area is acceptable.

The institute of good morals plays an important role in Slovak family law, although it is only explicitly mentioned once in the Family Act. It balances the mutual position of participants in family law relationships to contribute to a harmonious family life.

It has been observed many times throughout human history that the traditional family is second to none. Therefore, the traditional approach to Slovak family law is understandable. Moreover, it is essential to insist on traditional values and their observance not only in the family but in society as a whole. Divergent behavior contrary to these values could lead to various undesirable societal factors, such as crime, poverty, and divorce. It is much easier to prevent them by forming public opinion, and quality and consistent legislation play a significant role in this.

Art. 5: The best interest of the minor shall be the primary consideration in all matters affecting him or her. In determining and assessing the best interests of the minor, particular account shall be taken of:

a) level of childcare,

b) the safety of the child, as well as the safety and stability of the environment in which the child resides,

c) protection of the dignity as well as of the child's mental, physical and emotional development, 
d) circumstances related to the child's state of health or disability,

e) endangering the child's development by interfering with his or her dignity and endangering the child's development by interfering with the mental, physical and emotional integrity of a person who is close to the child,

f) conditions for the preservation of the child's identity and for the development of the child's abilities and characteristics,

g) the child's opinion and his possible exposure to a conflict of loyalty and subsequent guilt,

h) conditions for the establishment and development of relationships with both parents, siblings and other close persons,

i) the use of possible means to preserve the child's family environment if interference with parental rights and responsibilities is considered.

The principle of the best interest of the child is the guiding principle of all family laws. Some authors even consider it the basis of family law. ${ }^{17}$ This is not only based on domestic law, but also follows international law, particularly the Convention on the Rights of the Child ${ }^{18}$, in which it is mentioned repeatedly. This principle is most often identified with the general clause contained in the Convention on the Rights of the Child, specifically in Art. 3, which imposes an obligation to take into account all actions concerning children, whether undertaken by public or private social welfare institutions, courts of law, administrative authorities, or legislative bodies, the best interests of the child.

Despite the fact that several provisions of the normative part of the Family Act referred to the best interests of the child (e.g., §23, §24, §54, §59), as well as the provisions of special regulations (e.g., Act No. 305/2005 Coll. on the social legal protection of children and on guardianship, Act No. 176/2015 Coll., on the Commissioner for Children and the Commissioner for Persons with Disabilities, etc.), this term was not defined for a long time and its determining criteria were never established. By supplementing Art. 5 of the Family Act through an amendment to Act No. 175/2015 Coll., this important principle of the Convention on the Rights of the Child has gained its appropriate place in Slovak family law, namely by establishing it as a basic principle of the Family Act. The reason for this regulation was to emphasize the obligation of courts, as well as other bodies, which significantly interfere with the rights and obligations of children in their decisions, to proceed carefully and responsibly in their assessment of the circumstances of a particular case and to take into account the best interests of the child in all circumstances. It was not the intention to prescribe what is best for the child in each time and situation; therefore, the Family Act does not directly define the concept of the child's interest as such, and it should be determined according to the circumstances of the case and the needs of the child concerned. Each child is unique and, therefore, has specific needs. 
The state is obliged to take all the necessary measures to take into account the best interests of the child and to ensure that the best interests of children are taken into account in all actions of the competent authorities and public institutions whose decisions affect the rights of the child.

The best interest of the child is a complex, albeit flexible and adaptable, concept, the content of which must be determined based on specific cases. It needs to be adapted and defined based on the specific situation of the child concerned, taking into account the personal context, situation, and needs of the child. The concept of the best interests of the child, characterized by flexibility, makes it possible to respond to the situation in an individual manner. However, it also leaves room for manipulation. In assessing and determining the best interests of the child, it is necessary to consider the individual elements according to their relevance to the situation, while these are specific rights and not only elements of its determination.

General Comment No. $14(2013)^{19}$ on the right of the child to have his or her best interests taken as a primary consideration contains a list of elements to be taken into account when assessing the child's best interests. It provides the following elements: the child's views; the child's identity; the preservation of the family environment and maintaining relations; care, protection, and safety of the child; the situation of vulnerability; the child's right to health; and the child's right to education. The assessment of the best interests of the child considers all these elements, the weight of which is interdependent. It is obvious that not all elements will be suitable for each case, and the way in which the individual elements are used in different cases will be case-specific as well. Thus, the content of each element will vary for each child, depending on the specific circumstances. The importance of each element in the overall assessment of the case also varies. In specific cases, these elements of assessment and determination of the best interests of the child may even contradict each other. In such situations, the age and maturity of the child should be decisive for their balance, taking into account the child's level of physical, emotional, cognitive, and social development when assessing the child's maturity.

It is also necessary in this context to consider that the child's abilities evolve over time; therefore, decision-makers should impose measures that can be revised or adapted to the child's development and not make final and irreversible decisions. With this in mind, it is important to assess not only the child's physical, emotional, educational, and other needs at a particular moment, but also the child's possible development scenarios, and to analyze them in the short and long term. ${ }^{20}$

As seen from the above, the best interest of the child is not a new concept; however, its adoption into Slovak family law only happened in 2016 based on Act No. 175/2015 Coll., Amending and supplementing Act No. 36/2005 Coll. on the Family and Amendment of Certain Acts With this amendment, we see this principle reflected in the Family Act for the first time, specifically in the newly added Art.

19 UN CRC, 2013, art. 3, para. 1.

20 ibid. 
5. The principle was added as a non-hierarchical enumeration of the criteria. According to Art. 5, the best interest of the minor shall be the primary consideration in all matters affecting him or her. This provision in itself is rather vague; however, given the uniqueness of each child, a clear definition of the best interests of the child would not be appropriate. ${ }^{21} \mathrm{~A}$ uniform definition would make adaptability and flexibility impossible in the application practice, which are prerequisites for an individual approach to assessing a given child's situation. The various elements that need to be considered include, among others, the safety of the child, as well as the safety and stability of the environment in which the child resides; the protection of the dignity as well as of the child's mental, physical, and emotional development; the circumstances related to the child's health status or disability; the child's opinion and his possible exposure to a conflict of loyalty and subsequent guilt; conditions for the establishment and development of relationships with both parents, siblings, and other close persons, etc. The Family Act does not prioritize any of these criteria. It is up to the responsible authority to assess which element prevails as a starting point, taking into account the circumstances of the individual case. The flexibility and adaptability of the concept are also based on the possibility of relying on facts other than those mentioned in Art. 5 of the Family Act, as the enumeration of the criteria mentioned therein is not final or fixed. The implementation of this principle in the Family Act is necessary. Before 2016, public authorities involved in decision-making on children had a tendency to generalize, regardless of the specific circumstances of the case. Such an approach was in serious conflict with the obligations that obliged the Slovak Republic to respect the uniqueness of each child and its peculiarities. Slovakia generally has a major problem with the predictability of judicial decisions. To counteract this tendency to generalize, the best interest of the child was incorporated into the Family Act, enumerating the most important attributes of deciding on the best interests of the child in a demonstrative, non-hierarchical way. According to the legislator, the inspiration for formulating a legal definition in this manner was primarily General Comment No. 14 (2013) on the right of the child to have his or her best interests taken as a primary consideration. It was necessary to create a nonexhaustive and non-hierarchical list of elements that are crucial criteria and should be included in the assessment of the best interests of the child. The alphabetical order does not mean that one criterion takes precedence over others. In any case, it is important to consider the specific circumstances of the case.

Since the child has the status of a special subject and a weaker party, he or she requires increased protection to ensure the fulfillment of his or her rights. This is also the starting point of the Convention on the Rights of the Child itself, which introduced the notion of the best interests of the child, highlighting that it should be given priority in any action concerning children by public authorities, courts, and public or private welfare institutions. To defend the best interests of the child, it is essential to pay attention to the establishment of mechanisms at the national, regional,

21 Bános and Košútová, 2020, pp. 4-5. 
and local levels, as well as mechanisms and procedures for lodging complaints and appeals to fully realize the child's right to properly integrate their best interests by implementing measures and judicial and administrative proceedings relevant to or affecting the child. Parents have a primary duty to ensure the child's standard of living. It is the duty of the state to ensure that this obligation is and can be fulfilled.

The implementation of this principle in the Family Act is necessary. Before 2016, public authorities involved in decision-making on children had a tendency to generalize, regardless of the specific circumstances of the case. Such an approach was in serious conflict with the obligations that required the Slovak Republic to respect the uniqueness of each child and their peculiarities. Slovakia generally has a major problem with the predictability of judicial decisions. To counteract this tendency to generalize, the best interest of the child was incorporated into the Family Act, enumerating the most important attributes of deciding on the best interests of the child in a demonstrative, non-hierarchical way. According to the legislator, the inspiration for formulating a legal definition in this manner was primarily General Comment No. 14 (2013) on the right of the child to have his or her best interests taken as a primary consideration. It was necessary to create a non-exhaustive and non-hierarchical list of elements that are crucial criteria and should be included in the assessment of the best interests of the child. The alphabetical order does not mean that one criterion takes precedence over others. In any case, it is always important to consider the specific circumstances of the case. In conclusion, given the uniqueness of each child and their needs, a single definition of the concept of the best interests of the child would not be appropriate; on the contrary, it is necessary to maintain the flexibility and adaptability of this concept. In assessing the best interests, particular attention should be given to the circumstances relating to the individual characteristics of the child concerned, such as his or her age, sex, degree of maturity, experience, ethnicity, physical, sensory, or intellectual disability, and the social environment in which the assessed child lives, further circumstances such as the presence or absence of the child's parents and the quality of the child's relationship with the biological or surrogate family. The family is the basic unit of society and the natural environment for the growth and prosperity of its members, especially children. The Convention on the Rights of the Child (Art. 16) protects the child's right to family life. An important element of the system of this protection is the prevention of the separation of the child from the family environment and the preservation of the family as a unified community. Nevertheless, if the child is separated from one or both parents, he or she has the right: '... to maintain regular personal relations and direct contact with both his or her parents, provided that this is not contrary to his or her best interests.' Given the seriousness of the influence of the separation of the child from the parents, such a separation should occur only in the ultima ratio, that is, exclusively as the last solution to the situation, for example, if the child is at imminent danger of injury or in other necessary cases. Separation should not take place without first applying all the available measures to protect the child. Likewise, the child must not be separated from his or her parents because of a disability. If separation becomes 
necessary, decision-makers must ensure that the child maintains connections and relationships with his or her parents and family (siblings, relatives, and persons with whom he or she has a strong personal relationship), unless this is contrary to his or her best interests. If the child's relationship with the parents is interrupted, for example, migration (parents without a child or a child without parents), the obligation to maintain the family community must also be taken into account when assessing the best interests of the child in the context of decisions on family reunification.

\title{
4. The protection of matrimony in current Slovak legislation-the union of a man and a woman
}

\begin{abstract}
Marriage is a unique bond between a man and a woman. The Slovak Republic broadly protects and promotes its good. Marriage, parenthood and the family are under the protection of the law ${ }^{22}$ (Art. 41(1), Constitution of the Slovak Republic).

Marriage is a union of a man and a woman. The society comprehensively protects this unique union and helps its welfare. Husband and wife are equal in their rights and responsibilities. The main purpose of marriage is the establishment of a family and the proper upbringing of children ${ }^{23}$ (Art. 1 (Basic principles) Family Act No. 36/2005 Coll.).
\end{abstract}

The protection of marriage and families is explicitly laid down in two key legal acts in the Slovak Republic; one being the Family $\mathrm{Act}^{24}$ and the other the Constitution of the Slovak Republic itself. ${ }^{25}$ As discussed above, an adventurous road affected by historical changes impacted the current Slovak legislation. Slovak family law is very traditional - it does not recognize same-sex marriages or non-traditional forms of marriage; it does not define or protect cohabitation (regardless of the gender of the cohabitants). Besides these traditional principles being the basis of the Family Act, the most important ones have been elevated to a constitutional level.

\subsection{The protection of matrimony in the Family Act}

The legal regulation of marriage and its legal consequences form the basic predicament of Slovak family law and its legal regulation - Family Act No. 36/2005. Marriage is not of a contractual nature, but a union of a man and a woman, which is preferred by society in terms of starting a family and the proper upbringing of

22 Art. 41(1) Constitution of the Slovak Republic (460/1992 Coll.).

23 Art. 1, Family Act No. 36/2005 Coll.

24 Act No. 36/2005 on Family and on amendment of some other acts.

25 Constitution of the Slovak Republic (460/1992 Coll.). 
children. The legal regulation of marriage enables, among other things, the socially desirable stability of family relationships and the precise definition of rights and obligations arising from family functions, including the social records of marital relations. According to Art. 1 (Basic principles) of the Family Act of 2005, 'marriage is a union of a man and a woman. The society comprehensively protects this unique union and helps its welfare'. As evident from the wording, the basic approach of the legislator to the principle of marriage protection as a legally presumed relationship between a man and a woman, in contrast to the previous legislation, is also reflected in the fact that the new family law explicitly refers to the union of a man and a woman when defining marriage. We also distinguish between the unmarried cohabitation of a man and a woman from the marriage (the only legally protected union of a man and a woman), but the legal regulation of this institute is absent in our legal system. However, despite the fact that the given institute does not explicitly define the Slovak legal order, there are examples in Slovak legislation that address the specific legal claims of a partner in the cohabitation of a man and a woman although the relationship itself is neither defined nor protected in Slovak law, apart from certain claims. The basic principles of the protection of marriage are laid down in Art. 1 of the Family Act, where the legislator emphasizes the core principle of marital bonds in the Slovak Republic. It characterizes marriage as a unique union of a man and a woman, which completely excludes from the institute in question possible unions of persons of the same sex and other types of relationships, such as registered partnerships, which the Family Act does not mention in its terminology at all. The comprehensive protection of marriage and the need to help it prosper are also emphasized. Although the law identifies as the purpose of marriage the primary creation of a harmonious and lasting community of life, such as the family and, in connection with the family's reproductive function, the proper upbringing of children, we do not believe that childless couples should not be protected or that such marriages would not fulfill their mission. The purpose of marriage as set out in Slovak law is considered obsolete by many experts, who highlight that there are more and more childless couples due to medical reasons; however, the 2005 legislation considered the main purpose of a marriage to be the reproductive function and ultimately the proper upbringing of children.

According to the article in question, the husband and wife are equal in their rights and obligations both to each other and to others in society. They have a duty to live together, to be faithful, respect each other's dignity, help each other, take care of their children together, create a healthy family environment, and decide on family matters together. No discrimination is allowed in this relationship when it comes to rights and obligations.

When it comes to the legislation explicitly referring to marriage as a union of a man and a woman, this provision has been contested several times on the grounds of discrimination and human rights; however, both the Constitutional Court of the Slovak Republic and the Supreme Court of the Slovak Republic have upheld this 
principle as the core principle of family law and have not found Art. 1 discriminatory or in violation of human rights.

In 2012, the Supreme Court of the Slovak Republic held, in decision 5/2012, that 'the intention of the legislator was to allow the establishment of marriage exclusively to persons of different sex, and not of the same sex. ${ }^{26}$ In this case, two men turned to the Supreme Court because they were not able to enter into marriage and claimed that their fundamental constitutional rights were violated. The Supreme Court of the Slovak Republic, however, ruled that their rights were not violated; in fact, they were allowed to marry in accordance with the Constitution of the Slovak Republic and the Family Act. However, neither of these legal documents established a legal claim to the right of persons of the same sex to marry. As a result, even in this case, the fundamental right is granted to the plaintiffs as a constitutional right (subject to marriage to a woman). However, since the Family Act does not allow same-sex persons to enter into marriage, neither public administration bodies nor the court can act beyond their competence and the Family Act and allow them to enter into marriage, as they would violate Art. 2 par. 2 of the Constitution of the Slovak Republic and Art. 1 of the Family Act. Both the Constitutional Court and the Supreme Court have confirmed the basic principles of family law in Slovakia, and on this basis, marriage or registered partnership between persons of the same sex is prohibited in the Slovak Republic. The legislator clearly states that marriage can only take place between a man and a woman, that is, people of different sexes. The legislator considered the basic principles to be the legal expression of moral postulates. During the historical development of family law, moral norms already played an important role in the implementation of family law relations. It is specific to family law to adopt moral rules and give them a normative character. It clearly follows that the intention of the legislature was to allow marriages to be entered into exclusively by persons of the opposite sex. The Supreme Court also held that the Anti-discrimination Act could not be applied to the area of family law. This law regulates the application of the principle of equal treatment and provides for the means of legal protection in the event of a breach of this principle in the enshrined areas. The EU Charter of Fundamental Rights binding on EU Member States, in Art. 9, regulates the right to marry and the right to start a family, directly by reference to the national laws governing the exercise of these rights. It is clear from the Commentary to the Charter that the scope of the article in question is wider and includes other than traditional forms of marriage, provided that these are governed by the national law of each member state. Therefore, national legislation plays a key role. Art. 9 does not contain prohibitive restrictions on the right to marry. However, this does not imply that this is an absolute right. It is not possible for any couple, if they wish, to exercise their right to marry before a competent authority without fulfilling the legal conditions. The national legislation of most EU member states is based on the assumption that marriages are only allowed for couples of different sexes. Given the considerable

26 2Sžo / 5/2012 (NS SR). - Decision of the Supreme Court 5/2012. 
diversity of national rules on marriage, it can be argued that Art. 9 is drafted neutrally and expressis verbis does not determine the sex of persons who may enter into marriage. At the same time, there is a direct reference to national legislation, which in the case of the Slovak Republic very clearly states in the Constitution and in the Family Act that marriage is a union between a man and a woman.

Besides Art. 1 (Basic principles), the Family Act also defines the conditions of entering into marriage and the purpose of marriage further in $\S 1$, according to which 'marriage is a union of a man and a woman, which arises on the basis of their voluntary and free decision to enter into marriage after the fulfillment of the conditions stipulated by this Act.'

Based on the provisions of $\S 1$ of the Family Act, marriage is the oldest social institution and can be defined as the relationship between one man and one woman legally connected for life, to fulfill obligations to each other as well as to society and, as such, is founded on gender differences. Thus, in accordance with nature, tradition, morality, and social consent, Slovak law regulates marriage so that it serves the individuals of society and fulfills its natural, biological, personal, moral, family, and social tasks or mission. This provision of the Family Act is also strengthened and ensured by the Constitution of the Slovak Republic, Art. 41(1), which states at the highest normative level that: 'Marriage is a unique union between a man and a woman. The Slovak Republic broadly protects and promotes its good. Marriage, parenthood and the family are protected by law.'

The special protection of children is guaranteed, which means that marriage, as well as the family, is given the highest level of protection and the constitutional legal obligation of the state to assist this institution and to implement legislation that benefits marriage.

The definition of marriage implies monogamy; therefore, it is clear that it can only occur between one man and one woman. In direct connection with the provision of $\S 9$ of the Family Act, any bigamy (polygamy) is sanctioned by the invalidity of a later marriage. Sanctions at the criminal law level for the criminal offense of polygamy in the sense of $\$ 204$ of the Criminal Code might also apply.

Despite the legislation of some EU member states (such as France, Spain, Belgium, Denmark, the Netherlands, Portugal, Sweden, etc.) recognizing the so-called registered partnerships or de facto ties between persons of the same sex as legal institutes of marriage, Slovakia does not have legislation related to registered partnerships or similar legal institutions that would legalize same-sex unions, provide these with legal protection, or put these on an equal footing with an institute such as marriage. So far, there has been no binding legislation at the EU level that would require Member States to adopt a law on same-sex unions (marriages, registered partnerships). As mentioned above, there is no legislation in Slovakia; however, some claims could be formulated based on the provisions of private law. For example, inheritance law stipulates that inheritance claims are admissible in the case of those who lived with the deceased for at least one year before his death in the same household and who, for this reason, cared for the common household or were dependent on the 
guarantor. There is no stipulation of gender in this case, and this is not a type of marriage, or even registered partnership, but merely a claim recognized by the Slovak law based on private law. However, the position of the spouse is always protected as a matter of priority. Slovak legislation definitely favors marriage to other forms of cohabitation, for example, community property only exists between spouses; only spouses can adopt a child together; and they are also favored in the area of inheritance.

The basic condition for entering into a marriage is the voluntary decision of the woman and the man to enter into marriage. Thus, the wording of the law implies freedom in choosing a life partner. However, only persons with the capacity to marry may be the subject of a legal relationship such as marriage. This competence is not explicitly regulated by the Family Act, but it can be derived from the regulation of the so-called circumstances precluding marriage, also known as marital obstacles (see the provision of $\S 9$ Family Act). The purpose of this obligation is to prevent persons without the personal preconditions necessary for marriage (e.g., under-age or lack of mental maturity) from entering into marriage, contrary to the principle of monogamy, or where marriage is unsuitable due to biological and moral reasons (e.g., marriage between relatives). The lack of capacity to marry results in the invalidity of such marriages. Depending on the seriousness of the marital obstacle, it is declared either at the proposal of one of the spouses or ex officio. Incapacity to enter into marriage can be absolute (if the personal conditions for marriage to any person are not met) or relative (when the person is not qualified to marry only a particular person). An exception stipulated by the Family Act is the possibility of marrying a minor over the age of 16 . The marriage of such a person must be authorized by the court. The petitioner in question is a person who wants to enter into a marriage, and the participants are their legal guardians, most often their parents.

There is no legal right to issue a marriage permit; therefore, the court may decide not to allow a marriage. In doing so, the court examines various circumstances related to the couple - property, economic relations, maturity, relationship with the family, employment, whether one of the fiancés has been convicted for a crime, whether one is divorced, the perspective of the relationship, how long the relationship lasts, and so on. The court may also allow a person suffering from a mental illness to enter into marriage. The court proceedings in question are not subject to a court fee.

The Family Act, \$1(2), states, 'the purpose of marriage is to create a harmonious and lasting community of life that will ensure the proper upbringing of children.' This sentiment is also highlighted in Art. 1 (Basic Principles) as well as in the Constitution. Marriage has its purpose and goal, which is primarily the creation of a harmonious and lasting community of life and ensuring the proper upbringing of children. The addition of 'the proper upbringing of children is mainly' related to the reproductive function of the family in the marriage concerned. The proper upbringing of minor children, as one of the main purposes of marriage, does not merely consist of the superficial provision of their basic living needs or the material and better spatial equipment of the household but, especially, involves meeting the deeper emotional 
needs of minor children, creating opportunities for quality contact with children, preparing for future careers, etc. Based on the provisions of the Family Act, this upbringing should primarily be provided by the child's parents, ideally the spouses.

However, it is not possible to conclude from the diction of the law in question whether a marriage formed for a different purpose should be regarded as invalid. The Family Act does not examine the purpose for which the spouses enter into marriage but the seriousness of the spouses' will to enter into marriage, that is, they want to marry the other partner. However, a problem may occur if it is proven to be the so-called purposeful or sham marriage. Indeed, there is a growing concern in several EU member states that the institute of 'family reunification' is increasingly being abused as a means of obtaining residence in EU countries, combined with the many benefits of this institute. Abuse of the right to family reunification, in the form of a marriage of convenience, can be considered a form of illegal migration or an illegal way of obtaining residence in the country. Therefore, a marriage of convenience may be grounds for refusing an application for temporary residence. The police department may also administratively expel a national of a third country and ban him or her from entering the country for three to five years. He or she may also be fined up to $€ 1,600$ if he or she does not comply with the order to leave the country. Although the Slovak Republic does not currently have any bilateral or multilateral agreements with the EU or third countries aimed solely at combating the abuse of the right to family reunification and the prevention of marriages of convenience, it has concluded several police cooperation agreements in the fight against organized crime, which do not explicitly mention marriages of convenience or false declarations of parental responsibility, but aim, inter alia, to strengthen cooperation in the fight against illegal migration in general and in the area of illegal residence of persons.

While the Family Act clearly declares the upbringing of children as the main purpose of a marital union, marriage and having children in real life are not always interdependent. While the Family Act stipulates that the family environment formed by the child's father and mother is the most suitable environment for the all-round and harmonious development of the child, it also recognizes that not all children are born to married couples and also protects children born outside of a marital relationship without any discrimination. The purpose of the marriage is not conditional to the existence of a marriage; therefore, the inability to conceive and subsequently raise a child may not be grounds for marriage annulment or loss of capacity to marry. The connection between the purposes for which the spouses enter into marriage is therefore not absolute. It is important to note, however, that despite this, the legislator still found it necessary to include the purpose of marriage in the Family Act - highlighting the legal evolution and the current leading legal, cultural, and moral principles. While they might be considered conservative or even obsolete by some EU member states, these conservative principles are the very core of the legislation of the V4 countries - Slovakia included. 
The Family Act, \$1(3), states that a man and a woman who intend to enter into marriage (hereinafter referred to as 'fiancés') should know each other's character traits and health status in advance. Disagreements between the spouses' character and personality traits and different views on life, household functions, the upbringing of children, and finances are some of the most common causes of marital breakdown and subsequent divorce. For this reason, the Family Act introduced the obligation for spouses entering into marriage to know each other's characteristics and health status to prevent the negative consequences of reckless and superficial marriages. In addition to fulfilling this obligation to know each other's character, priorities, goals, personal structure, or values, the couple should, at least to some extent, identify with these. At the same time, they need to know each other's characteristics, priorities, and expectations from marriage and combine them to avoid later disappointment, frustration, and, ultimately, divorce. However, as this is an imperfect norm, failure to comply with this legal requirement does not affect the validity of the marriage, even if such concealment was intentional. In addition to their character traits, both fiancés should be aware of their mutual health status. The importance of this fact is also presented in the statement itself, which the couple makes before the marriage (see $\$ 6$ of the Family Act). The term 'health status' should be understood not only as physical but also as mental health. Of course, the law does not require mandatory preventive medical examinations before entering into marriage. However, it is the moral duty of each fiancé to find out his or her health status and, in the case of genetic disorders, degenerative diseases, untreatable diseases, fertility disorders, or sexually transmitted diseases, to inform their partner so that he or she can freely and seriously make an informed decision about getting married.

The current legislation distinguishes between two forms of marriage depending on the authority before which the spouses make a declaration of consent. Both the civil form (at the registry office - the municipality or city district competent to keep the registry) and the ecclesiastical form (before the church - the registered church or registered religious society) have an equal status in relation to legal effects related to marriage. The right to choose the form of marriage is the exclusive right of the partners. Therefore, if they are unable to agree on a choice, neither the court nor any other competent authority can make this decision for them (this is based on the premise that the state may intervene in family relationships only if the relationship enjoys protection under the law). Both civil and ecclesiastical marriages have constitutive effects. It is also possible to choose both forms of marriage, but only if the couple has made its initial declaration before the registry office, that is, in the civil form. The subsequent ecclesiastical form represents only a spiritual rite in the sense of the internal regulations of the given church and has no other legal effects. The first statement of consent before a competent authority has constitutive effects, that is, at the very moment the marriage is founded. If the couple decides to marry before a church body, the subsequent civil form is no longer possible.

In addition to the clash between civil and ecclesiastical marriage, the couple may, depending on their faith, be faced with the choice of church and religious 
society. In this case, the legal order attributes the constitutive effects to the first ceremony; the other ceremony does not affect the personal status of the spouses. An exception is a situation in which one church is not registered by the Ministry of Culture of the Slovak Republic. In such a case, the constitutive effects of the spouses' declaration of marriage are associated with a marriage held before a body of the registered church. Church leaders hold different perspectives on this matter. The so-called mixed marriage, for example, marriage between a Catholic person and a person baptized in another church, can be conducted only with the prior permission of the ecclesiastical authority.

For the spouses' declaration of marriage to have constitutive effects, they must meet the conditions clearly listed in the Family Act, namely:

- Public ceremony,

- Solemnity of expression,

- The presence of two witnesses,

- Orality,

- Addressability.

In the absence of any of the above requirements, the marriage in question would be non-matrimonium, that is, it would not occur.

The condition of the public ceremony of the marriage is maintained unless access to the ceremony is prevented. However, an extensive interpretation of this requirement is out of the question; therefore, no explicit notification of the planned ceremony can be required. The participation of two witnesses in the solemn declaration of the spouses is needed because of the possibility of additional validation of the certificate of marriage later on. Therefore, personal participation and full legal capacity are essential. Their ability to understand the language in which the marriage ceremony is conducted, the ability to reproduce its course, and the ability to sign the marriage certificate are required. Witness status is voluntary and cannot be enforced. The solemnity of expression is determined by several aspects. The first aspect is the venue for the ceremony. To preserve the ceremonial form of civil marriage, there are criteria for the visual design of the ceremony room (decoration, placement of the coat of arms, etc.) as a special room adapted for wedding ceremonies, or other suitable place determined by special regulations of the municipality and city. Solemnity is also given in the ecclesiastical form of marriage, where the law explicitly establishes a church or other suitable place determined by the internal regulations of the church and religious society as the place for the ceremony. Solemnity is also ensured by the person performing the ceremony, who can only be the mayor, or another authorized member of the local (city) council. In the case of a church ceremony, it is a person performing the activity of a spiritual registered church or religious society. However, dignity and solemn expression are also given through other circumstances, such as the intercession, traditions, and dressing of those present. Despite these apparently essential elements of the prenuptial act, failure to observe the condition of solemnity, as in the case of the publicity of the ceremony, has no legal consequences for the 
conclusion and validity of the marriage. The oral form of the ceremony is ensured by clear and comprehensible speech in the form of an answer to a question aimed at ascertaining the seriousness of the spouses' will to enter into marriage with each other. The oral form presupposes that both fiancés (as well as their witnesses) understand the language in which the ceremony takes place; otherwise, an interpreter should be asked to interpret the given act. In principle, however, the legal system does not clearly preclude making an act of declaration in another way, one that does not cast doubt on what the party intends to express (e.g., by a clear nod of the head).

\subsection{The protection of matrimony in the constitution}

Slovak family law is very traditional; it does not recognize same-sex marriages or non-traditional forms of marriage, and it does not define or protect cohabitation (regardless of the gender of the cohabitants). Besides these traditional principles being the basis of the Family Act, the most important ones have been elevated to the constitutional level. Marriage is a legal relationship between one man and one woman. This is the first premise of family law. It has also been part of the Constitution of the Slovak Republic since 2014.

The previous version of the Constitution only stipulated that 'matrimony, parenthood and the family shall be protected by law.' In 2014, however, the description of marriage as the union of one man and one woman was elevated to the constitutional level by amending Art. 41 of the Constitution of the Slovak Republic. Since the creation of the independent Slovak Republic, two attempts have been made to provide legal protection to same-sex registered partnerships. The public rejected these attempts, but in the early 2010s, the population started to warm up to the idea of registered partnerships. However, this public perception swiftly changed to a more conservative one after the ruling of the European Court of Human Rights in the case of $X$ and Others v. Austria 53 ILM 64 in 2013. This ruling was the first recognition of the right of unmarried same-sex couples to second-parent adoption in European states that are a party to the European Convention on Human Rights. The ruling, while celebrated in many EU member states, had an adverse effect on the more traditionally inclined Slovakia, where the idea of same-sex couples being allowed to adopt children was not accepted well by the public. Following societal pressure, the Constitution was amended to state, 'Marriage is a unique union between a man and a woman. The Slovak Republic broadly protects and promotes its good. Marriage, parenthood and the family are protected by law.' This principle had already existed in the aforementioned Family Act from 2005; however, elevating it to the constitutional level implies much stronger protection of this principle. While the principle had existed in our legal order before, it was only granted constitutional protection in 2014. The explanatory report of the constitutional amendment stated that based on this definition, 'marriage therefore cannot arise between persons of the same sex'. The explanatory report was not expertly written. It did reference international law (in particular, Art. 12 of the Convention for the Protection of Human Rights and 
Fundamental Freedoms and Art. 16 of the Universal Declaration of Human Rights); however, the explanatory notes failed to correctly interpret the relevant provisions of international law.

It is important to emphasize that this is not a new principle, contrary to what the media coverage of the amendment sometimes suggested, but an already existing principle of family law in Slovakia, which was newly introduced to the Constitution as well. As marriage is the basic institution of family law relations, its protection in the Constitution is self-explanatory and is a matter of public interest. Despite the extensive media coverage brought about by this adopted amendment to the Constitution of the Slovak Republic, the amendment did not affect people's lives since it was something that had already existed in the Slovak legal order.

This public perception was further used to fuel a referendum in 2015, titled 'On the Protection of Family.' The referendum, organized by the Alliance for Family, was held on February 7, 2015, with the following three questions:

1. Do you agree that no cohabitation of persons other than a union between one man and one woman can be called marriage?

2. Do you agree that same-sex couples or groups should not be allowed to adopt and raise children?

3. Do you agree that schools should not require children to participate in education pertaining to sexual behavior or euthanasia if the parents or the children themselves do not agree with the content of such education?

A fourth question aimed at banning registered partnerships was invalidated by the Constitutional Court of the Slovak Republic. Voter participation barely exceeded 21 percent, rendering the referendum invalid.

The evolution of family law in the past decade in Slovakia is a clear example of how ideological pressure can have counterproductive effects. The EU has exercised some pressure on its member states to equalize and protect both the traditional and the non-traditional family. This pressure and the ruling of the European Court of Human Rights led Slovak legislators to feel the need to give a higher level of protection to traditional, conservative family law principles.

\section{Protection of families in current Slovak legislation}

The previous chapter of this report dealt with the protection of matrimony and the definition of a marital relationship under Slovak law. There are, however, some very interesting principles not only guiding the protection of marriages but specific to the protection of families present in Slovak legislation.

The importance of the family as part of the life and destiny of the vast majority of humanity and its immense importance for society itself has led and constantly 
leads to the interest of many scientific and non-scientific disciplines in this concept, its essence, content, and its changes in the 21st century. This law is no exception. However, each field of study devotes a different space to the family and provides a different view. Most dictionaries provide several general definitions of a family, for example, 'a group consisting of two parents and their children living together as a whole,' 'a group of persons connected by blood or marriage,' 'all descendants of the same ancestor.' From a sociological perspective, a family is a group of persons connected by marriage, blood, or adoption, who form one household and interact with each other; they are usually spouses, parents, children, and siblings. The family is not a foreign concept even in psychology, where it is perceived as a social group connected by marriage or blood, responsibility, and mutual assistance. Finally, a family is subject to regulation, legal order, and the interest of legal science. Legal theory often does not define a family but only describes it through rights and responsibilities. When it comes to the Slovak Republic, it is necessary to point out the absence of a legal definition of a family, despite the fact that this term is used in several legal regulations in both private and public law, and, of course, in the Family Act itself. The closest to a definition is the formulation in the Family Act, which states 'family founded by marriage is the basic cell of society. Society comprehensively protects all forms of the family.' This cannot, of course, be considered a definition of the family, as it cannot be stated from the first sentence in the context of the second sentence that the family arises only by marriage. There is no legal definition of a family, or even a similar definition anywhere in the Slovak legal order. The interpretation of the concept of a family is equally relevant from the point of view of case law, particularly the case law of the European Court of Human Rights. The European Convention for the Protection of Human Rights and Fundamental Freedoms enshrines the protection of private and family life in its Art. 8, but it does not provide a definition of a family and leaves it to the judiciary. In this context, it should be noted that the absence of any legal definition of a family can be considered advantageous, as it leaves room not only for the existence of atypical forms of families but also in no way restricts existing ones and, at the same time, allows itself to interpret this concept as needed in order to align social reality with legal theory.

Many of the principles of family law were enshrined in the Slovak legal system from a more conservative approach to families than in most EU member states; therefore, these principles unique to Slovak family law are worth exploring.

Art. 2 (Basic principles) of the Family Act discusses the protection of families. Based on Art. 2 a 'family founded by marriage is the basic cell of society. Society comprehensively protects all forms of the family.' The Family Act highlights marriages that have fulfilled their main purpose and have created a family, which forms the basis of society and which society is committed to protecting comprehensively. A family is a bond between at least one parent and at least one child. In principle, it is not possible to discriminate marriages that have remained childless, as marriages are also provided with protection in Art. 1 of the Family Act. It can therefore be assumed that the protection provided under Art. 2 is a special type of protection, as it provides 
protection for families with children - either established by marriage and ensuing reproduction or formed on the basis of blood relationships or adoption.

The Act (Art. 3) further highlights the main purpose of marriage as that of upbringing children.

Parenting is an extremely important mission of women and men recognized by society. Society recognizes that a stable family environment formed by the child's father and mother is the most suitable for the all-round and harmonious development of the child. The society provides parenthood not only with its protection, but also with the necessary care, especially with material support for parents and assistance in the exercise of parental rights and obligations.

One of the basic functions of a family is reproduction, which is highlighted several times throughout the text of the Family Act of 2005. The parental role is an important part of an adult's identity, which is socially valued and recognized, as reflected both in the provision of parental protection and in the material support of the family by the state (parental allowance, child allowance, childbirth allowance, maternity allowance, childcare allowance, etc.).

With an amendment to the Family Act in $2015,{ }^{27}$ this principle was further strengthened by explicitly identifying the 'family environment formed by the child's father and mother' as the most suitable environment for the all-round and harmonious development of the child. According to the explanatory report, this is primarily to express the belief that the competent authorities and institutions, whose decisions may affect the child and their rights, are obliged to respect the fundamental rights of the child, depending on the circumstances, of course. This emphasizes the importance of the child's parents for the versatile and harmonious development of the child. The legislator refers to Art. 7 of the Convention on the Rights of the Child, according to which every child has the right to know his or her parents and be cared for by these parents. ${ }^{28}$ In addition, as mentioned in Pt. II of Point 3 of the United Nations (UN) Guidelines on Substitute Care for Children, given that the family is a fundamental cell of society and a natural environment for the growth, well-being, and protection of children, efforts should be made to keep children with their parents, return them to the care of their parents, or, if that is not possible, to the child's close relatives. The statement supplemented by the amendment on the most suitable environment, together with the addition of the principle of the child's interest (Art. 5 of the Basic Principles of the Child Protection Act), should highlight the child and his or her rights as an equivalent element of family law relations. This addition is followed by the regulation of the conditions of institutional care and provisions on the sequence of forms of alternative care, where priority is given to care

27 Act No. 175/2015 Coll.

28 Art. 7. Convention on the Rights of the Child Adopted and opened for signature, ratification and accession by General Assembly resolution 44/25 of 20 November 1989. 
provided by parents, relatives, and persons close to the child; if such persons are not available, foster care comes into play and, as the ultima ratio solution, institutional care comes into play. ${ }^{29}$

\section{Alternatives to traditional matrimony and family in Slovak legislation}

As discussed in the previous chapters of this report, the Slovak family law is conservative in nature. This is explicitly reflected in the Constitution and Family Act. If we look at the legal framework of the country, we quickly discover that there is no alternative to traditional marriage in the Slovak legal system. Slovakia does not recognize same-sex marriage, registered partnerships, or civil unions. Cohabitation is not recognized either; however, certain rights and responsibilities can be derived from a cohabiting relationship according to civil and penal law, which does not mean that cohabitation is in any way regulated by the Family Act or that partners in such a relationship would have rights equal to those in a marital relationship. It is merely a 'close person' living in the same household.

Cohabitation is often viewed as an invention of these past few revolutionary decades as an alternative to marriage; however, a closer look into history actually shows that cohabitation has existed in some forms in all eras of human history. The legal regulation of this institute and the legal interpretation of cohabitation are, indeed, a new development. Cohabitation is an institute that exists in the reality of the Slovak Republic, and the law only touches on it marginally. It is a phenomenon that is not specifically defined or protected in Slovak law; however, there are certain claims of the cohabitants that are recognized by Slovak law. The primary reason for this discrepancy between the reality of everyday life and legal theory is the rather conservative nature of Slovak family law, which stems from its historical evolution.

In recent years, we have seen what many refer to as the crisis of the traditional family based on the marital union of a man and a woman in Slovakia. This crisis is clearly apparent in the growing rate of cohabiting relationships ${ }^{30}$ and a relatively high divorce rate. At the same time, we have seen several unsuccessful legislative attempts to grant legal recognition to an institute that would be an alternative to marriage (be it heterosexual or same-sex). Family law in Slovakia has very traditional foundations, and, as such, it protects the institute of a traditional marriage above all. This does not mean that other unions are not protected at all; on the contrary, it guarantees the protection of all families, regardless of their form, if they provide a sense of safety to their members, which includes stable long-term 
cohabiting relationships. ${ }^{31}$ One of the criticisms of the Family Act from 2005 is that it does not address the issue of cohabitation. Neither the Civil Code nor the Family Act defines, regulates, or protects cohabitation in Slovakia; however, the institute does have certain legal consequences.

The family can be described as a social group formed by individuals bound by marriage, blood relationships, or adoption. Family members follow established patterns of behavior, and each family member fulfills a certain social role. According to the Slovak Family Act, the family is the basic cell of society and is established by marriage as a union of a man and a woman, which arises on the basis of their voluntary and free decision to enter into marriage after the fulfillment of the conditions laid down by law. The purpose of marriage is to create a harmonious and lasting community of life that will ensure the proper upbringing of children. At present, there is no precise universal legal definition of the term 'family.' The case law of the European Court of Human Rights is based on the broader concept of family, which is not only a union based on marriage, it goes beyond a marital union.

Views on marriage and family continue to evolve and change as society evolves. Lately, our society is witnessing a declining motivation for young people to enter into marriage, but even today, marriage remains highly valued. From the point of view of marriage, it is interesting that some unmarried heterosexual couples are not eager to enter into marriage for several reasons, while homosexual couples demand the legalization of their relationships. Lately, we can see a trend of various alternative forms of marriage gaining popularity. While the Family Act might not reference these forms of relationship or provide them with legal protection, it is clear that the law will have to catch up and provide a regulatory framework for these types of relationships as well. Bills to recognize registered partnerships were introduced four times in Slovakia, in 1997, in 2000, in 2012, and in 2018, but they were all rejected. Slovak society does not seem to be ready for that; however, it should be noted that in addition to the traditional marriage, the number of couples in cohabitation is rising, and this is not just true for same-sex relationships. Given that unmarried relationships, such as cohabitation, are not legally regulated as marriage, it is important to recognize that these relationships require certain protection, especially considering social security law or insurance law. As mentioned above, while the Family Act does not recognize cohabitation, there are other areas of Slovak law where we might find certain protection and even various legal consequences of a cohabiting relationship.

One of the areas worth mentioning is the field of social insurance, where a closer look at the legislation unveils certain gaps. An important component of social insurance is health insurance, through which persons are financially secured in the event of a social event such as illness, injury, the need to care for a person, pregnancy, or maternity ${ }^{32}$. The benefits of health insurance are dependent on the occur- 
rence of the illness or injury, regardless of whether the persons involved are married, unmarried, or single.

An example is the need to treat a sick person, which implies the person's entitlement to one of the health insurance benefits, namely nursing care. The provision of this allowance is regulated by Act No. 461/2003 Coll. on Social Insurance, as amended (hereinafter referred to as the 'Social Insurance Act') ${ }^{33}$. Pursuant to this Act, an insured person is entitled to a nursing allowance if they care for a sick child, sick husband, sick wife, sick parent, or sick parent of a spouse whose health condition, according to the doctor's certificate, necessarily requires treatment by another person. It follows from the above that the provision of this benefit is conditioned by an indirect and adverse social event, which, in most cases, is the illness of a person defined by the Social Insurance Act.

Nursing benefit, as an obligatory cash benefit of health insurance from the point of view of married and unmarried couples, belongs only to the insured person who treats a sick spouse. In the case of unmarried persons, even if they live in a common household, if one of them becomes ill, the other is not entitled to a nursing allowance. The exclusion of cohabiting couples from the circle of eligible persons was caused by the new legislation, which was introduced on January 1, 2004. The negative impact of this legislative change is apparent in the case of couples living in cohabitation. For example, an insured person lives in the same household as the mother of his children in an unmarried relationship. In this case, unlike married spouses, if the mother or father becomes ill, the other insured person is not entitled to a nursing allowance. We believe that in the legislative amendments to the Social Insurance Act, there should certainly be an expansion of the range of beneficiaries entitled to this benefit.

The same gaps in legislation can be seen in the nursing benefits in relation to a child. For the purposes of the Social Insurance Act, a child refers to the child of the insured person, the adopted child of his or her spouse, or a child entrusted to the insured person in care replacing parental care at the decision of a competent authority. ${ }^{34}$ In the absence of adoption or entrustment to care replacing the care of the parents on the basis of a decision of a competent authority, the insured person is also not entitled to a nursing care allowance for the child of an unmarried partner, even if they live in the same household.

There are also some disparities between married and unmarried persons in terms of pension insurance. The main role of pension insurance is to ensure sufficient income for individuals during adverse social situations, mostly of a long-term nature, such as old age, disability, and loss of the breadwinner of the family. While there are no differences in claiming any of the basic pensions for married and unmarried persons, the existence of a marriage is required for survivors' pensions (widows' and widowers' pensions). This follows from the provision of $\$ 74$ the Social Insurance Act, according to which a living spouse is entitled to a widow's pension (for 
a deceased husband) and a widower's pension (for a deceased wife). If the persons are not married and live in the same household for a long time and possibly also have children together, if one of these persons dies, the right to a survivor's pension does not arise, which in our opinion is debatable. We believe that even in this case, it would be desirable to extend the circle of beneficiaries of these persons. Such legislation would not be an exception, as in many jurisdictions, the circle of persons entitled to a survivor's pension is wider, as it is based on closer family involvement and a higher dependency on income in the wider family; therefore, entitlement arises, for example, to the parent, grandson, sibling, companion, or divorced wife of the deceased. ${ }^{35}$ According to the Slovak Health Care Act, only the spouse has the right to access the medical file after the death of their spouse. ${ }^{36}$ The same applies to an adult living in the same household as the deceased at the time of their death, but only if there is no surviving spouse, child, or parent of the deceased. ${ }^{37}$

Tax law also shows discrepancies between partners in cohabitation and married spouses. According to the Income Tax Act, the tax base calculated from the income of a person is reduced by the tax allowance per spouse. ${ }^{38}$

As mentioned above, Slovak society does not seem to be ready to introduce samesex partnerships into the legal framework. However, the question remains: should we provide heterosexual couples with an alternative to traditional marriage given that the number of cohabitations is rising each year, or is the current legislation sufficient? While we are standing at a crossroads of reforming Slovak family law and there will be an opportunity to rethink our interpretation of marriage and family, many scholars and legislators remain reluctant to introduce an alternative to traditional marriage.

\section{Conclusion: The future of family law in Slovakia}

In the area of private law, especially in the law of obligations, there has been an effort to comprehensively harmonize and unify the various legal systems, if not on a global scale, at least on a pan-European scale. These works began in the second half of the twentieth century. Family law has long been resistant to the challenges of internationalization, if not globalization. The possibility of harmonizing family law based on the area of social relations that it regulates was perceived very carefully until 1970, and family law itself was considered to be an area of law based on the unique historical, cultural, and social aspects of each country and are deeply rooted in the values of the people. 
Some authors ${ }^{39}$ also take the view that family law is unsuitable for harmonization or Europeanization, in view of the various cultural, religious, moral differences, and traditions within Europe or the world in general. However, the family knows no boundaries. Current trends and harmonization efforts in the field of family law in the legal environment of Europe and the European Union consist of research, especially of a comparative nature.

Nevertheless, it can undoubtedly be stated that important reforms of family law are happening, not only at the academic level but also at the level of European Union legislation, and legislation on family law is being adopted, albeit predominantly of a procedural nature or extending into private international law. However, the work of the European Union Court of Justice, especially the work of the European Court of Human Rights, cannot be neglected. International legislation, case law, and international documents all have a significant impact on the evolution of family law, and their influence cannot be understated. In addition to harmonization through legislation, there is a significant convergence of individual legal systems thanks to academics and their influence. The Commission on European Family Law, established in 2001 and has, in addition to many publications or reports, also published the Principles of European Family Law (which focuses mainly on divorce and maintenance obligations between ex-spouses, parental responsibility, responsibilities, and property relations between spouses), is particularly important in this context. I would also mention the Central European Professors' Network. While there are many global, international, or EU-wide research projects, it is often forgotten that the V4 countries and the surrounding region share a piece of history that undoubtedly formed their values and views on legislation. It is therefore extremely important to collaborate with academics and legal practitioners across the countries in this region in the area of family law.

The Europeanization of family law, as well as current societal changes, seems to be an inexhaustible source of not only inspiration but also conflicting and controversial opinions in society, as family law is the area that affects the most intimate area of every person's life. The main objective of this country report was not only to provide answers to current problems but also to summarize these problems and ask questions to stimulate a broader discussion about these ongoing changes in our society. In terms of Slovakia, it should be noted that at present, with regard to the recodification of the Civil Code, there is a unique opportunity for change, which does not occur often. Family law cannot become a field for political war or propaganda; it must respect the unique historical and societal attributes and values of the country and serve, above all, to protect families and the best interests of the child. This study highlighted the need for discussion on controversial topics, thus enabling the creation of a code worthy of the 21st century, which would reflect the values of this region and could subsequently be an inspiration for many other codifications. 


\section{Bibliography}

BÁNOŠ, R. KošÚtovÁ, M. (2020) Zákon o rodine - Vel'ký komentár. Žilina: EuroKódex.

BlAir, D., Weiner, M., STARK, B. AND MALDONADO, S., N.D. (2009) Family law in the world community. Carolina: Carolina Academic Press.

DовоŠ, I. (2021) Verejné zdravotné poistenie v podmienkach Slovenskej republiky. Bratislava: Paneurópska vysoká škola.

KENNEY, C. AND MCLANAHAN, S. (2006) 'Why are cohabiting relationships more violent than marriages?' Demography, 43(1), pp. 127-140; https://doi.org/10.1353/dem.2006.0007.

Kovac, P., ERdosova, A. (2020) Právo na informácie o zdravotnom stave vo vybraných otázkach aplikačnej praxe. Bratislava: Bulletin slovenskej advokácie.

KRÁLIČKovÁ, Z. (2003) Autonomie vůle v rodinném právu v česko-italském porovnání. Brno: Masarykova univerzita.

KRÁLIČKOVÁ, Z. (2015) Czech Family Law: The Best Interest of the Child. Brno: Masarykova univerzita

SprochA, B., VANo, B., BleHA, B. (2014) Prognóza vývoja rodín a domácností na Slovensku do roku 2030. Bratislava: Vydavatel'stvo Ekonóm.

StAVrovA, O. (2019) 'Having a Happy Spouse Is Associated with Lowered Risk of Mortality', Psychological Science, 30(5), pp. 798-803.

Troster, P. (2013) Právo sociálního zabezpečení. Praha: C.H. Beck

UECKER, J. (2012) 'Marriage and Mental Health among Young Adults', Journal of Health and Social Behavior, 53(1), pp. 67-83; https://doi.org/10.1177/0022146511419206.

\section{Legal sources}

Act No. 11/1918 Reception Act

Act No. 175/2015 Coll., Amending and supplementing Act No. 36/2005 Coll. on the Family

Act No. 320/1919 Coll. Marriage Amendment

Act No. 36/2005 Coll. on Family and on amendment of some other acts

Act No. 461/2003 Coll. on Social Insurance as amended by later regulation

Act No. 576/2004 Coll. on Health Care

Act No. 595/2003 Coll. on Income Tax

Act on Family Law No. 265/1949 Sb.

Constitution of the Slovak Republic No. 460/1992 Coll.

Convention for the Protection of Human Rights and Fundamental Freedoms. Council of

Europe Treaty Series 005, Council of Europe, 1950.

Decision of the Supreme Court 5/2012 - 2Sžo / 5/2012 (NS SR).

Family Act No. 94/1963 Coll.

International Covenant on Civil and Political Rights

Marriage Act (Act XXXI/1894)

UN Committee on the Rights of the Child (CRC), General comment No. 14 (2013) on the right of the child to have his or her best interests taken as a primary consideration

UN General Assembly, Convention on the Rights of the Child, 20 November 1989, United Nations 